\title{
DR. WINIFRED HOERNLÉ: AN APPRECIATION
}

\section{MAX GLUCKMAN and I. SCHAPERA}

\section{$\mathrm{D}$} R. AGNES WINIFRED HOERNLE (née Tucker), formerly Senior Lecturer in Social Anthropology at the University of the Witwatersrand, who died in Johannesburg this year, was born at Kimberley in 1885 . Mrs. Hoernle studied philosophy at the South African College (now University of Cape Town) and anthropology at Cambridge; she also attended courses at the Sorbonne and two German universities. On returning to South Africa, she carried out field researches among the Nama Hottentots of Cape Colony and South West Africa (1912 and 1913), and also collected some information from Herero. In 1923 she began to lecture in Social Anthropology at the University of the Witwatersrand, where her husband and former teacher, R. F. Alfred Hoernlé, was Head of the Department of Philosophy. Professor Radcliffe-Brown had recently become the first Professor of Social Anthropology at the University of Cape Town, and Mrs. Hocrnlé was largely influenced by him, as by the school of Durkheim, in her approach to the study of social life. This shows strongly in the few but important articles she published on the social organization and rituals of the Hottentots and Southern Bantu, and in several more general papers. Her intellectual interests, however, remained catholic: she taught, and even wrote occasionally, on prehistory, and maintained a continuing interest in psychology and philosophy. In the course of her academic duties, incidentally, she also built up a museum at the University of archaeological specimens and of the material culture of African tribes.

Together with her husband she later entered upon a strenuous career of social work for the peoples of South Africa, both in specific welfare organizations and in the general field of race relations. This led her to study the changes affecting the African population and its indigenous culture, and she both taught on those changes, and wrote briefly about the problems involved, when such topics were not yet well established as part of social anthropology.

Mrs. Hoernlé was a brilliant, inspiring, and warm-hearted teacher, who not only excited in her students an enthusiasm for the subject, but developed close affectionate ties with them. Some (e.g. Ellen Hellman, Eileen Krige, Hilda Kuper, and Max Gluckman) themselves became professional anthropologists. But her influence extended far wider. Through her undergraduate classes she spread tolerance and understanding of the many peoples of the Union, based on knowledge of their cultural riches and their common humanity. She knew many Government officials and missionaries, whom she encouraged to record their knowledge of the peoples among whom they worked. Above all, she readily and graciously assisted everybody who came to study the human problems of the country, and she continued to stimulate scholars long after resigning from her university post in 1937 to devote herself to the care of her aged father and mother-in-law. Anthropologists going to any part of SouthCentral Africa were always welcome visitors at her home, and all testify to the keenness of her mind, and to an intellectual vigour that enabled her to discuss their 
problems fruitfully with them even when the main interests of the subject had changed.

Her husband shared all her interests, and few anthropological seminars have been more stimulating and rewarding than informal meal-time discussions with the two of them. His death in 1943 was a severe blow; but she continued to work even harder in their many activities. She was recognized as a leading authority on South African affairs, even by Governments which she frequently castigated. She served as a member of the Union Government Penal and Prison Reform Committee in 1947, and her evidence was quoted with respect by other Government Commissions. She stamped indelibly the development of the South African Institute of Race Relations, of which her husband had been President for twenty years. She herself was its President for two years, and its vice-president for many more. That her interests were not confined to one section of the population is shown by a far from complete list of the offices she held: Chairman of the Standing Committee for Non-European Child Welfare, President of the Johannesburg Child Welfare Society, Vice-Chairman for the Transvaal and the Chairman of Executive of the South African Council for Child Welfare, member of the National Welfare Organizations Board, member of the Penal Reform League of South Africa, \&c. She took a particularly keen interest in the Indians of the Union, for she thought their case was least well presented, and she was Chairman of the Johannesburg Indian Social Welfare Association. She also presided over African school committees, until the Bantu Education Act compelled her to relinquish those offices.

The University of the Witwatersrand acknowledged her services to anthropology and to the nation when, in 1949, it conferred upon her an honorary Doctorate of Laws. Her own pupils and colleagues in South African anthropology had paid tribute to her many years before with a special issue of Bantu Studies in September 1935, on the occasion of her fiftieth birthday; she enjoyed the almost unique distinction, for a British subject, of being made an Honorary Fellow of the Royal Anthropological Institute; and for her seventieth birthday the S.A. Institute of Race Relations dedicated to her an issue of its journal, entitled 'Homage to Winifred Hoernle'. The preface cites an incident that illustrates both her deep sense of humankindness and her intellectual vigour. Mrs. Hoernlé led the deputation from the Institute of Race Relations to give evidence to the Commission on the Socio-Economic Development of the Native Areas, and she was the main spokesman through two days, ' giving of the wisdom acquired during a lifetime of work. When it was over and the Institute had been thanked for its evidence and had given thanks for the courteous hearing received, the Chairman sat back and said: "Mrs. Hoernle, you are a remarkable woman." '

Her death leaves those of us who knew her well with an abiding sense of sorrow, but also of grateful recollection of a life so well spent in the service of science and, even more markedly, in the defence of basic human rights. 